\title{
SOFTWARE KONSULTASI SELEKSI KARIR SISWA MENGGUNAKAN METODE
} CERTAINTY FACTOR

\author{
Irwan*1, Gustientiedina $^{2}$, Alyauma Hajjah ${ }^{3}$, Yenny Desnelita ${ }^{4}$, Wilda Susanti ${ }^{5}$ \\ 1,2,3,4,5 Institut Bisnis dan Teknologi Pelita Indonesia \\ Email: 1irwan@lecturer.pelitaindonesia.ac.id, ${ }^{2}$ gustientiedina@lecturer.pelitaindonesia.ac.id, \\ ${ }^{3}$ alyauma.hajjah@lecturer.pelitaindonesia.ac.id, ${ }^{4}$ yenny.desnelita@lecturer.pelitaindonesia.ac.id, ${ }^{5}$ wilda@lecturer. \\ pelitaindonesia.ac.id \\ *Penulis Korespondensi
}

(Naskah masuk: 29 September 2018, diterima untuk diterbitkan: 01 Februari 2021)

\begin{abstract}
Abstrak
Model software konsultasi seleksi karir sebagai alternatif pengambilan keputusan dimana konsultasi meliputi pemahaman karir, perencanaan karir, alternatif pilihan karir yang berupa alat penelusuran minat dan bakat siswa terhadap keputusan karir siswa menggunakan metode certainty factor berbasis sistem pakar. Penelitian ini menghasilkan model software konseling dalam memperoleh informasi penting tentang pengembangan karir siswa dan membantu memfasilitasi perkembangan individu siswa melalui bentuk layanan agar mampu merencanakan karirnya berdasarkan jurusan, minat, bakat, pengetahuan, kepribadian, kompetensi dan faktorfaktor lain yang mendukung kemajuan dirinya dalam menentukan pilihan dan keputusan yang sesuai dengan dunia kerja pilihan siswa.Sistem diuji menggunakanwhite box dan black boxdengan menunjukan hasil dimana sistem dapat digunakan sesuai kebutuhan.
\end{abstract}

Kata kunci: software konsultasi, seleksi karir, certainty factor, keputusan karir

\section{CAREER SELECTION CONSULTATION SOFTWARE OF THE STUDENTS USING CERTAINTY FACTOR METHOD}

\begin{abstract}
Career selection consulting software model as an alternative decision making where consultation that includes career understanding,career understanding, career planning, alternative career choices in the form of a tool to trace students' interests and talents towards student career decisions using expert system based certainty factor method. This research produces a counseling software model in obtaining important information about student career development and helps facilitate individual students development through a form of service in order to be able to plan his career based on majors, interests, talents, knowledge, personality, competencies and other factors that support his progress in determining choices and decisions that are appropriate to the world of work choice. The system is tested using white boxes and black boxes by showing the results where the system can be used as needed.
\end{abstract}

Keywords: consulting software, career selection, certainty factors, career decisions

\section{PENDAHULUAN}

Bimbingan dan konseling merupakan kegiatan yang bersumber kepada siswa, para siswa tidak sama potensi diri yang mereka miliki satu dengan lainnya dalam minat - bakat maupun kemampuannya dalam mengambil keputusan karir masa depan. Informasi mengenai keputusan karir tidak didapati dengan tepat.Pada akhirnya siswa mengambil keputusan karir masa depan dengan keputusan yang tidak tepat dengan potensi diri yang dimiliki siswa. Bimbingan karirdalam pemilihan karir yang tepat dengan jurusan dan minat-bakat yang dimiliki siswa dalam perencanaan karir setelah lulus dari SMK perlu di lakukan bimbingan melalui konsultasi dan melakukan pembimbingan karir yang diminati siswa. Bimbingan karir merupakan sebuah hal yang paling penting unntuk mengarahkan siswa sesuai dengan minat, bakat dan potensi yang dimilikinya. Untuk mencapai peluang kerja bagi lulusan Sekolah Menengah Kejuruan,diperlukan upaya untuk perencanaan danpengembangan karir dimana salah satu cara yang lakukan oleh siswa adalah menggabungkan kompetensi, minat, bakat, motivasi dan prestasi. 
Software seleksi karir siswa dibuat menggunakan metode Certainty Factor (CF), karena dengan menggunakan metode $\mathrm{CF}$ dapat menghasilkan tingkat kebenaran, keakuratan dari semua kemungkinan pemilihan karir.

Penelitian oleh Cojocariu and Ciotir (2015)menyatakan dalamkonteks pengembangan layanan karir di Rumania dimana kebutuhan untuk menasehati siswa meningkat, tujuan penelitian untuk mengidentifikasi hubungan antara kebutuhan akan konseling, keterlibatan aktif individu dalam proses konseling karir yang dihadiri oleh siswa dengan menggunakan kuesioner yang menghasilkan arah tindakan baru. Dimana layanan bimbingan dan pengembangan karir yang dilaksanakan disekolah bertujuan membimbing para siswa untuk dapat mengenal lebih dini potensi dirinya, minat-bakatnya dan lapangan kerja sesuai jurusan, kompetensi siswa itu sendiri dalam berkarir didunia kerja setelah lulus nantinya.

Dapat dikatakan bahwa individu siswa dapat bekerja dengan baik dan tekun dilapangan kerja, memerlukan adanya kesesuaian antara lapangan kerja dengan kompetensi, minat-bakat dan potensi diri individu siswa. Supaya dapat mengarahkan hal tersebut maka diperlukan bimbingan dan konsultasi dalam penyeleksian karir siswa secara baik. Dalam penelitian yang berisi mengintegrasikan motivasi dalam konseling karir, motivasi mendapat perhatian khusus dibidang konseling karir, yang dapat membantu dalam keputusan karir siswa (Robert dan Rossier, 2016). Selanjutnya penelitian tentang ketersediaan layanan konseling karir dikalangan siswa dan hubungan dengan perolehan keterampilan berwirausaha untuk menghindari pengangguran lulusan (Garce dan Ihuoma, 2013). Robert dan Brown (2013) telah meniliti penggunaan model Social Cognitive Career Theory (SCCT) yang menyediaakan atau menyajikan model kognitif sosial manajemen karir dan menawarkan contoh perilaku karir misalnya pengambilan keputusan karir, pencariaan kerja dan kemajuan karir. Dalam penelitian Choi et al. (2012)menyatakan tes model CSM saat ini didasarkan pada penelitian sebelumnya yang telah meneliti hubungan antara variabel model yang relevan dalam konteks eksplorasi karir dan pengambilan keputusan.

Berpedoman dari beberapa hasil penelitian diatas maka dalam makalah ini dibuat sebuah program atau softwarekonsultasi seleksi karir dalam membantu siswa mengambil keputusan karir bijaksana serta realistis. Layanan bimbingan konseling karir dapat dilihat sebagai proses pengarahan siswa kepada dunia kerja nantinya dimana siswa dapat mengembangkan dan menerima gambaran diri sendiri secara menyeluruh, dan peranan siswa dalam dunia kerja. Pentingnya informasi atau pengetahuan tentang karir yang membantu mengenal pekerjaan yang sesuai dengan minat bakat dalam diri siswa.
Penelitian pada Expert System (ES) telah menjadi salah satu bidang penelitian terpanjang yang pernah ada dan paling berhasil dalam bidang Artificial Intelligence (AI). Penelitian yang menggunakan expert system berisi sejumlah besar informasi tentang pengembangan $E S$ dan bagaimana alat, konsep, dan aplikasi telah dikembangkan sejak awal. Dengan ukuran sampel yang begitu besar, hasilnya sangat membantu dalam mengidentifikasi bagaimana $E S$ telah berevolusi dan area untuk penelitian lebih lanjut (Wagner, 2017).

Menurut fenomena, penelitian ini meneliti komponen model perancangan perangkat lunak konseling bimbingan dan pengembangan karir siswa yang dapat mendukung komunikasi tentang perencanaan dan pengembangan karir siswa di masa depan.

\section{METODE PENELITIAN}

\subsection{Expert System}

Sistem pakar dalam disiplin Artificial Intelligence (AI)pada makalah ini digunakan untuk merancang pengetahuan yang didapat dari seorang ahli atau pakar dimana sistem pakar ini nantinya dapat membantu sistem menyerupai keahlian seorang pakar dalam menjawab pertanyaan dalam memcahkan masalah pengguna menyelesaikan proses pengambilan keputusan secara benar. Penelitian di Expert System (ES) telah menjadi salah satu bidang penelitian terpanjang yang pernah ada dan paling berhasil dalam bidang $A I$. Sejak tahun 1980an, banyak studi kasus aplikasi $E S$ telah publikasikan yang mencakup berbagai area fungsional dan domain masalah. (Wagner, 2017).

Dimana ESmempunyai tiga komponen utama yang harus ada yaitu berupa knowledge base, motor inferensi dan antarmuka pengguna diillustrasikan pada gambar 1. Knowledge base berisi semua pengetahuan yang didapat dari ahli seperti pengetahuan, fakta, peraturan. Motor inferensi mengeksikusi tindakan untuk menghasilkan informasi yang memenuhi persyaratan berupa aturan(rule). Terakhir, antarmuka pengguna menawarkan interaksi dengan pengguna non-pakar, dimana pengguna menjawab pertanyaan atau masukan data untuk memulai proses logis pada mesin inferensi. Dua metode inferensi yang biasanya digunakan dalam melakukan penelusuran rule untuk menghasilkan informasi atau solusi yaitu metode forward chaining dan backward chainig (Ozden, dkk., 2016). 


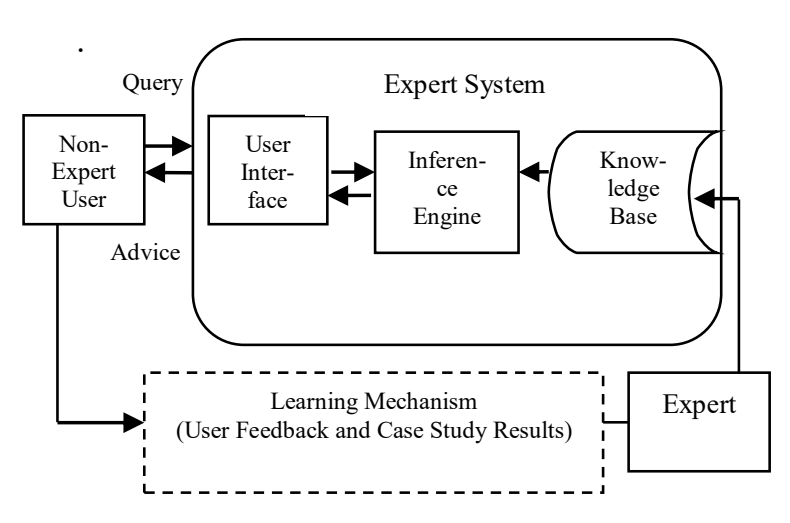

Gambar 1. Arsitektur dari Sistem Pakar

\subsection{Desain Sistem Pakar Untuk Konseling Karir}

Rancang software konseling karir adalah untuk memungkinkan pengguna mendapatkan informasi dan keuntungan dari pengetahuan tentang konseling karir yang menggunakan sistem pakar dimana dapat mensimulasikan penilaian dan perilaku manusia yang memiliki pengetahuan dan pengalaman ahli dalam bidang konseling karir. Dalam desain dan pengembangan software konseling karir berbasis sistem pakar menggunakan shell software bimbingan dan pengembagan karir. Software bimbingan dan pengembagan karir memiliki penjelasan fasilitas pertanyaan basis pengetahuan dan saran yang diberikan. Softwarebimbingan dan pengembagan karir berisi aturan yang direpresentasikan dalam sintak untuk basis pengetahuannya. Ini terdiri dari fasilitas untuk menulis aturan yang membangun basis pengetahuan.

Untuk mengembangkan software konseling karir, pertama perlu kita mengidentifikasi masalah dan memahami karakteristik masalah yang harus kita pecahkan dalam software konseling karir. Masukan masalah untuk software konseling karir berupa alat ukur konseling karir yang berfokus pada pengukuran bimbingan dan pengembangan karir siswa. Masukan masalah terstruktur untuk software konseling karir dan pola modul ahli untuk mendapatkan solusi jika ada. Dengan adanya software konseling karir ini maka dapat meningkatkan pengambilan keputusan dan konsultasi bimbingan dan pengembangan karir siswa, sehingga pemilihan karir siswa akan lebih menjadi efektif didalam melakukan konseling.

Basis pengetahuan didalam pengembangan sistem pakar merupakan bagian yang paling penting karena kualitas sistem pakar tergantung pada pengembangan basis pengetahuan. Basis pengetahuan dengan bantuan ahli tertentu dalam sistem pakar ini dikembangkan dengan software bimbingan dan pengembagan karir. Proses pengembangan sistem pakar menggunakan software bimbingan dan pengembagan karir adalah proses banyak langkah yang bertujuan untuk mengembangkan basis pengetahuan yang spesifik. Langkah-langkah untuk mengembangkan basis pengetahuan dalam sistem ini adalah demulai dengan identifikasi masalah masukan, akuisisi pengetahuan dan representase pengetahuan dalam basis pengetahuan yang dapat di jelaskan pada gambar 2.

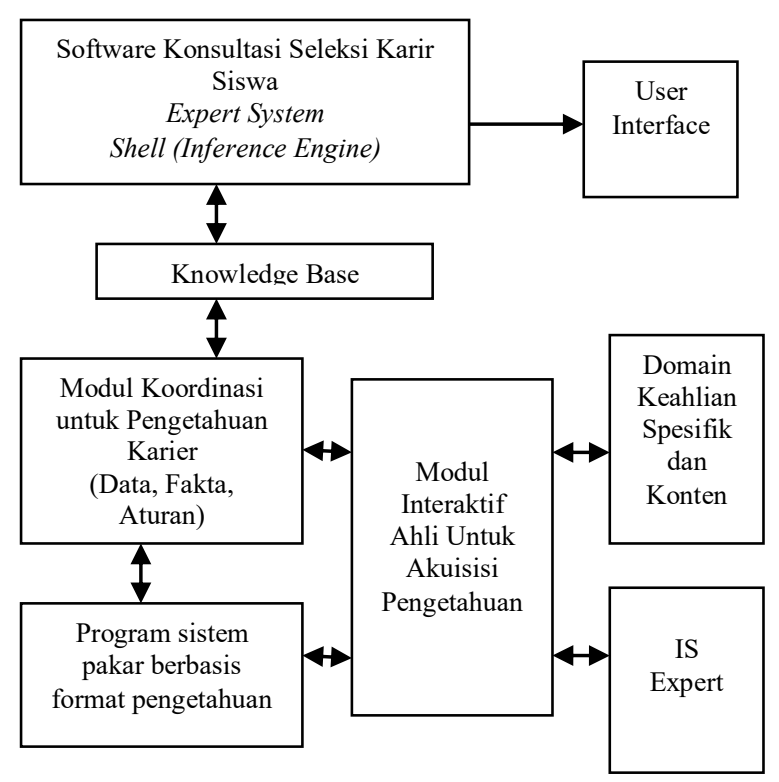

Gambar 2. Arsitektur Panduan Perangkat Lunak Seleksi Karir Berbasis Sistem Pakar

\subsection{Akuisisi Pengetahuan Konsultasi Seleksi Karir.}

Akuisisi pengetahuan digunakan untuk mengumpulkan fakta-fakta basis pengetahuan yang akan diproses pada suatu masalah. Proses akuisisi dalam sistem pakar ini memiliki modul interaktif ahli, program sistem pakar dan modul koordinasi untuk database pengetahuan. Dalam modul interaktif ahli domain pengetahuan keahlian khusus diperoleh dari tenaga ahli. Pengetahuan yang digunakan sebagai informasi dalam menganalisis, mengolah yang diorganisasi dengan terstruktur menjadi basis pengetahuan dan kemudian di proses untuk mendapatkan kesimpulan terbaik dalam masalah karir siswa pada konsultasi seleksi karir. Pengetahuan ini kemudian ditransfer ke IS Expertuntuk memverifikasi, mengkonversi kedalam program sistem pakar konseling karir. Proses ini dilanjutkan sampai pada menemukan solusi yang terbaik terhadap masalah. Setelah pengetahuan yang diperoleh dari pakar dan diverifikasi olehIS Experts, kemudian dipindahkan dari modul interaktif ahli setelah itu modul program sistem mengkonversikan ke dalam program sistem pakar. Untuk software bimbingan dan konseling karir, pakar pengetahuan diperoleh dari literatur standar yang terkait dengan bimbingan dan pengembangan karir. Dengan demikian proses akuisisi pengetahuan telah dilakukan melalui serangkaian sub modul interaksi yang terintegrasi dengan modul koordinasi untuk menciptakan database pengetahuan sampai diperoleh 
kesimpulan atau solusi terbaik. Berdasarkan asumsi yang didapat dari ahli atau pakar serta untuk membantu penggunaan metode CFperlu didefinisikan suatu range dalam memberikan pembobotan nilai digunakan skala likert 4 titik, $1=$ kurang, 4 = sangat baik.

\subsection{Model Representasi Pengetahuan dalam Basis Pengetahuan}

Representasi pengetahuan merupakan fase terakhir dari pengembangan basis pengetahuan. Representasi pengetahuan dalam basis pengetahuan, pengetahuan yang diperoleh dari proses akuisisi pengetahuan diwakili dalam bentuk struktur. Ada banyak pendekatan untuk mewakili pengetahuan ke dalam basis pengetahuan dengan menggunakan representasi berbasis aturan dalam paradigma logis sederhana menggunakan aturan If-then pada backward danforward chaining. Makalah ini dalam merepresentasikan pengetahuan menggunakan ifthen aturan dengan forward chaining.

Sistem pakar ini terdapatdua representasi pengetahuan utama yaitu bagian dan parameter.Tingkat atas dari representase pengetahuan dalam softwarebimbingandan pengembangan karir berbasisexpert system adalah bagian yang berisi aturan logis mengarahkan sistem pakar bagaimana memecahkanmasalah sepertimemberikan pertanyaan dan menjawab pertanyaan beserta saran atau solusi karir yang dipilih oleh siswa. Saran yang diberikan jika kondisi pada bagian terpenuhi. Parameter yang digunakan sebagai variabel kontrol menentukan aliran antara bagian dalam basis pengetahuan. Parameter variabel ada 4 jenis yang digunakan yaitu boolean atau logis, teks, jumlah dan kategori parameter. Parameter boolean atau logis digunakan ketika jawaban dari pertanyaan yang diajukan adalah sangat baik, baik, cukup atau kurang. Nilai untuk setiap parameter dihitung dari respon pertanyaan pengguna, melalui parameter lain atau sebagai hasil dari penerapan aturan.

Pada makalah ini teknik analisis yang dipakai adalah analisis pemilihan dan pengembangan karir siswa dengan menggunakan certainty factor. Analisis ini merupakan teknik multivarian yang mempunyai tujuan membantu memecahkan masalah dengan kepastian perhitungan yang mempunyai beberapa variabel. Dalam makalah ini, representase pengetahuan yang digunakan berbasis aturan dalam basis pengetahuan bimbingan dan pengembangan karir. Bimbingan dan pengembangan karir dibagi menjadi 3 tahap (Nusai et al., 2015)yaitu :

1. Langkah Pertama : career screening

Peneliti menetapkan model baru representase pengetahuan menggunakan minat dan bakat siswa yang didefinisikan oleh konselor. Model representasi pengetahuan untuk bimbingan dan pengembangan karir yaitu pengetahuan dalam bentuk aturan dinyatakan sebagai persamaan (1)

If $\mathrm{F}$ and $\left(\mathrm{B}_{1} \mathrm{OR} \mathrm{B}_{2} \mathrm{OR} \ldots \mathrm{OR} \mathrm{B}_{\mathrm{n}}\right)$ then $\mathrm{H}$

Where, $\mathrm{F}$ adalah Jurusan;

B1, B2, ..., Bn adalah minat dan bakat;

\section{$\mathrm{H}$ adalah karir}

Jika pengguna memasukan jurusan dan karir sesuai dengan aturan, aturan tersebut digunakan untuk konsultasi bimbingan dan pengembangan karir menurut minat dan bakat maka hasil menunjukan kemungkinan karir yang cocok sesuai dengan minat dan bakat siswa.

2. Langkah kedua : penelusuran karir menggunakan minat dan bakat

Peneliti menetapkan model baru representasi pengetahuan yang tidak pasti dengan mentukan bobot signifikan setiap karir, yang ditetapkan oleh konselor. Pada masing-masing penelusuran, pengguna juga harus menentukan faktor kepastian karir yang diminati siswa. Model representasi pengetahuan yang tidak pasti untuk penelusuran karir menggunakan variabel minat dan bakat. Pengetahuan dalam bentuk aturan dinyatakan sebagai persamaan (2),

If $\mathrm{e}_{1}\left(\mathrm{w}_{1}\right)$ AND $\mathrm{e}_{2}\left(\mathrm{w}_{2}\right)$ AND $\mathrm{e}_{3}\left(\mathrm{w}_{3}\right)$ AND $\ldots$ AND
$\mathrm{e}_{\mathrm{n}}\left(\mathrm{w}_{\mathrm{n}}\right)$ THEN H $(\mathrm{CF}, \mathrm{Min})$

Dimana, $\mathrm{e}_{1}, \mathrm{e}_{2}, \mathrm{e}_{3}, \ldots$, en adalah minat dan bakat; wi $(\mathrm{i}=1,2,3, \ldots, \mathrm{n})$ adalah karir yang signifikan, $\sum_{i=1}^{n} \mathrm{w}_{\mathrm{i}}=1$

$\mathrm{H}$ adalah Karir

CF adalah Certainty Factor of rule; min adalah minimum yang diterima, $\mathrm{CF}$ dan Min ditentukan oleh konselor

Untuk bukti, $\mathrm{E}=\mathrm{e}_{1}\left(\mathrm{w}_{\mathrm{i}}\right)$ AND $\mathrm{e}_{2}\left(\mathrm{w}_{2}\right)$ AND $\mathrm{e}_{3}\left(\mathrm{w}_{3}\right)$ AND ... AND $\mathrm{e}_{\mathrm{n}}\left(\mathrm{w}_{\mathrm{n}}\right)$

Perhitungan Faktor Kepastian E(CF(E)) menggunakan persamaan (3)

$\mathrm{CF}(\mathrm{E})=\sum_{i=1}^{n}\left(\mathrm{CF}\left(\mathrm{e}_{\mathrm{i}}\right) \mathrm{x} \mathrm{w}_{\mathrm{i}}\right)$

Dimana, $\mathrm{CF}\left(\mathrm{e}_{\mathrm{i}}\right)$ adalah faktor kepastian terjadinya karir yang diminati, nilai tersebut ditentukan oleh pengguna. Nilai Certainty Factor antara adalah 0 sampai 1.

Perhitungan faktor kepastian karir $(\mathrm{CF}(\mathrm{H}, \mathrm{E}))$ menggunakan persamaan (4).

$\mathrm{CF}(\mathrm{H}, \mathrm{E})=\mathrm{CF}(\mathrm{E}) \mathrm{XCF}$

Jika $\mathrm{CF}(\mathrm{H}, \mathrm{E}) \geq \mathrm{Min}$, aturan ini digunakan untuk penelusuran karir dan hasilnya menunjukan kemungkinan karir siswa sesuai minat dan bakat.

3. Langkah Ketiga : Konsultasi karir using lesion

Model representasi pengetahuan untuk konsultasi karir menggunakan lesing. Pengetahuan dalam bentuk aturan dinyatakan sebagai persamaan (5) LS1 AND LS2 AND...AND LSn OR (LM1 OR LM2 OR...OR LMn) Then H

Dimana:

LS1, LS2, ... LSn adalah lesi pada kelompok lesi utama

LM1, LM2, ... LMn adalah lesi adalah kelompok lesi minor 
$\mathrm{H}$ adalah konsultasi karier

Jika pengguna memasukkan semua lesi pada kelompok lesi utama, maka aturan tersebut digunakan untuk konfirmasi morbiditas (Nusai et. al., 2015)

\subsection{Proses Inferensi}

Konsultasi bimbingan karir dan pengembangan menggunakan inferensi ke depan.Proses inferensi dibagi menjadi tiga tahap. Langkah pertama adalah inferensi dalam konsultasi karir, kesimpulan dimulai dari pengambilan karir; langkah kedua adalah inferensi dalam penelusuran minat-bakat dan langkah, kesimpulan dimulai dari menjawab pertanyaan minat bakatdan memasukan certainty factoruntuk menghitung $\mathrm{E}(\mathrm{CF}(\mathrm{E})$,kemudian menghitung faktor kejadian terjadinya minat bakat $(\mathrm{CF}(\mathrm{H}, \mathrm{E}))$, dilakukan seleksi aturan dan dibuat penelusuran masing-masing. Hasil penelusuran yaitu kemungkin karir siswa; langkah ketiga adalah kesimpulan karir, kesimpulan mulai mengambil lesion masukan dan membuat penelusuran masingmasing. Hasil penelusuran adalah morbiditas.

\section{HASIL DAN ANALISIS}

Berdasarkan dari hasil analisis dan perancangan Irwan et, al., (2017) dalam artikel yang menyatakan model rancangan software konsultasi dalam pemilihan dan pengembangan karir siswa yang dapat melakukan pengambilan keputusan karir serta sebagai media konsultasi menggunakan metode certainty factor untuk menghasilkan nilai kebenaran tentang pilihan karir siswa yang sesuai dengan jurusan, minat-bakat, kompetensi maka dibuat software menggunakan expert system berbasis web.

Dalam makalah ini, menggunakan penerapan model representasi pengetahuan dan inferensi dalam menghasilkan kesimpulan atau solusi karir siswa. Bila pengguna mengisi minat bakat melalui pertanyaan maka faktor kepastian karir siswa akan muncul sebagai solusi atau kesimpulan karir siswa tersebut. Sistem pakar berbasis web untuk software bimbingan dan pegembangan karir siswa terdiri dari mengisi potensi diri yang berisi minat bakat, mencari dan menunjukan karir, solusi karir menggunakan certainty factor, web board, basis pengetahuan, mesin inferensi, pengelolaan data dan database. Aplikasi sistem pakar berbasis web dikembangkan oleh ColdFusion Markup Language (ColdFusion 8), mengelola sistem database adalah SQL Server 2008 dan menguji perangkat lunak dengan pengujian Black-Box (Nusai et. Al., 2015). Aplikasi web dibuat dengan HTML, CSS, dan Javascript (Rizal.A.Z et. Al., 2018).

\subsection{Diagram Alir Sistem}

Software seleksi karir siswa memiliki tujuan untuk melakukan konsultasi seleksi karir siswa dengan berpedoman kepada potensi diri siswa yaitu minat-bakat, motivasi dan kompetensi yang dimiliki siswa. Pada halaman awal, ditampilkan menu-menu untuk menelusuri karir siswa. Setelah pengguna memilih menu-menu pada software yang dirancang, akan ditampilkan antarmuka untuk mulai melakukan tes karir dengan menjawab beberapa pertanyaan yang ada di sistem. Diagram alir sistem dari aplikasi konsultasi seleksi dan pengembangan karir siswa yang memberikan informasi jalannya software, dimana tergambar sistematika alur kerja sistem yang dibuat. Dalam diagram alir menjelaskan bagaimana user melakukan konsultasi dengan sistem atau aplikasi yang dapat di ilustrasikan pada gambar 3 .

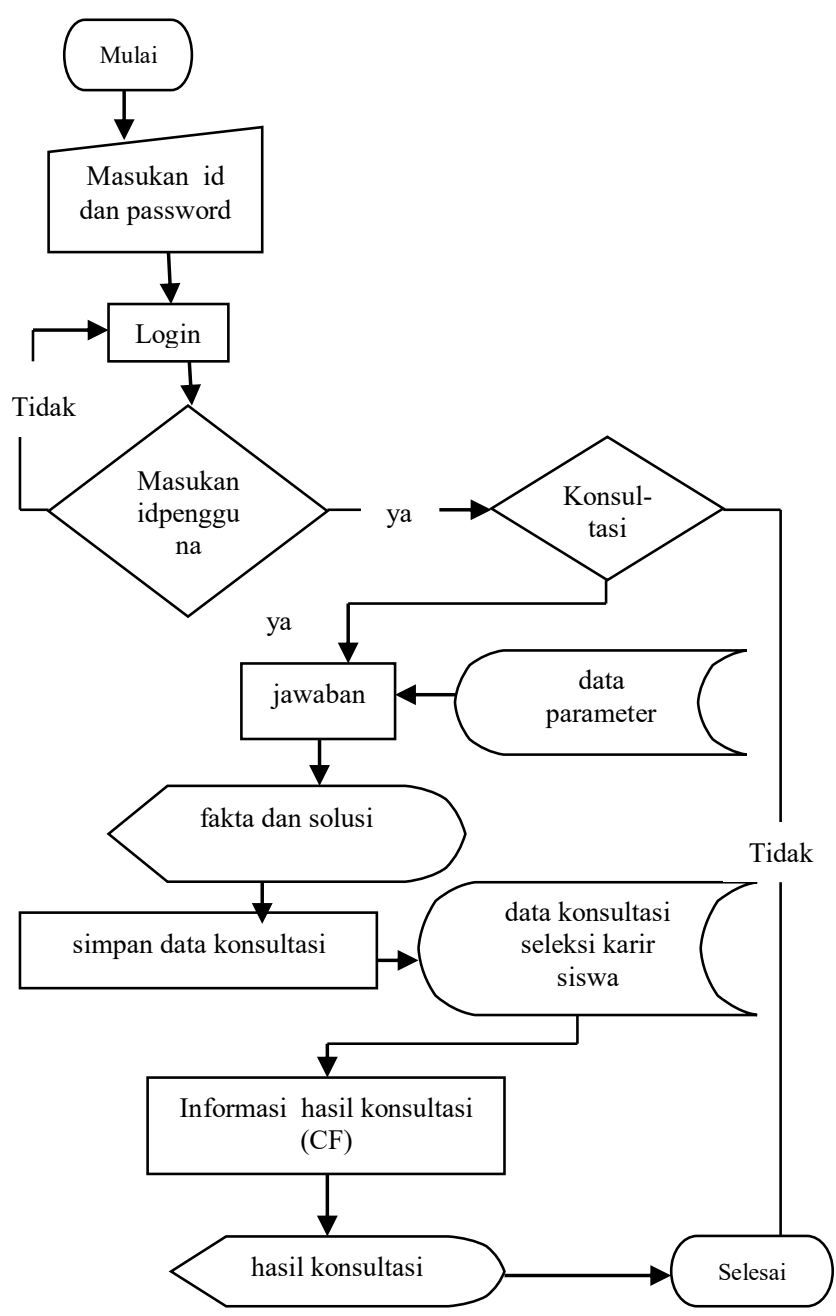

Gambar 3. Diagram Alir Sofware Konsultasi Seleksi Karir Siswa

Dalam makalah ini CFdigunakan untuk menghitung kemungkinan karir yang cocok dari menjawab pertanyaan yang diberikan sistem dengan kesesuaian jurusan, minat-bakat, kompetensi siswa untuk kemudian diambil nilai densitas (kepercayaan) pada setiap jawaban pengguna yang sesuai dengan 
fakta. Setelah didapatkan nilai densitasnya maka dapat dilakukan identifikasi jawaban. Pada gambar 3 diagram alir mesin inferensi, menggambarkan proses inferensi $C F$ sebagai penarik kesimpulan dalam pencarian solusi. Sedangakn gambar 4 menggambarkan proses perhitungan metode Certainty Factor.

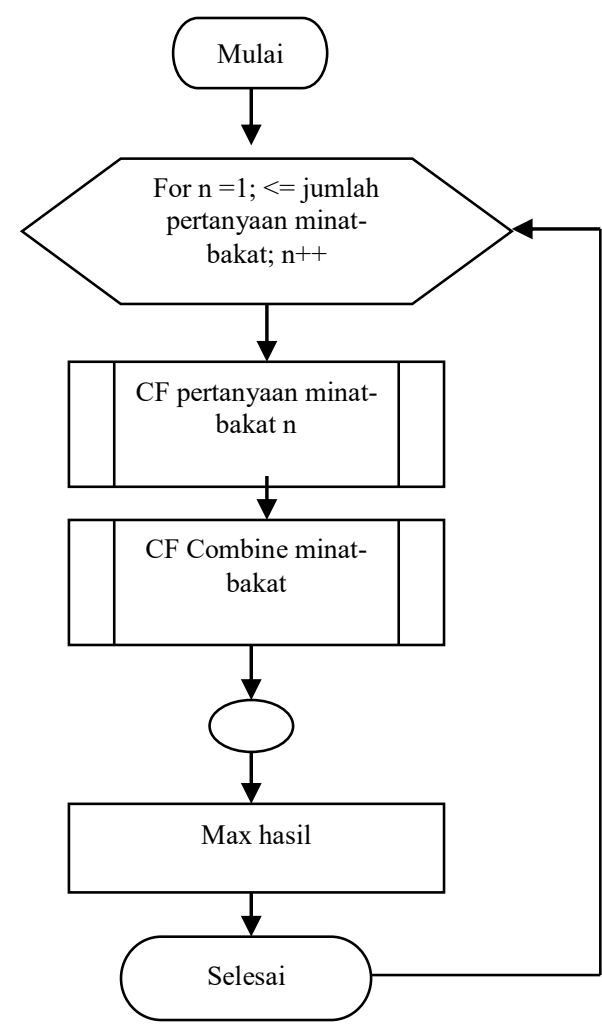

Gambar 4. Diagram alir Perhitungan Certainty Factor (CF)

\subsection{Expert System Dalam Konsultasi Seleksi Karir}

Sebuah aturan yang digunakan dalam sistem konsultasi seleksi karir dalam makalah ini menggunakan paradigma logis aturan if-then. Dalam implementasi software konsultasi seleksi karir menggunakan CFuntuk melakukan identifikasi jawaban solusi karir siswa.Software konsultasi seleksi dan pengembangan karir siswa menggunakan perhitungan yang meliputi beberapa pertanyaan minat-bakat. Proses identifikasi ini dengan memasukan fakta-fakta berupa test potensi diri melalui minat-bakat siswa yang kemudian dilakukan proses identifikasi menggunakan algorithma $C F$.

Sistem memiliki halaman aplikasi untuk memudahkan pengguna dalam melakukan konsultasi karir yang dapat dijabarkan pada gambar 5 sampai gambar 7.

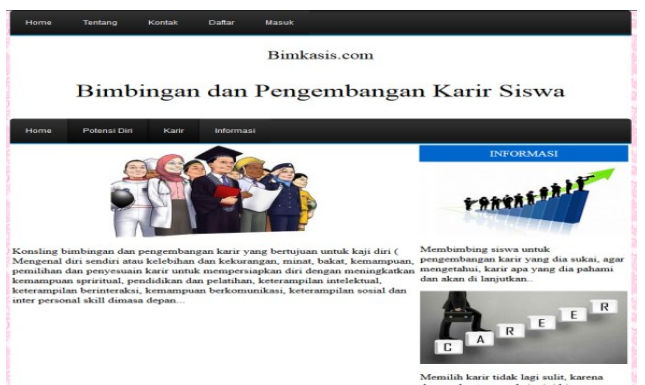

Gambar 5. Halaman Utama Konsultasi Seleksi Karir Siswa

Pada gambar 5 menampilkan menu utama dari aplikasi bimbingan seleksi dan pengembangan karir siswa. Siswa dapat memulai bimbingan dengan panduan menu utama diatas.

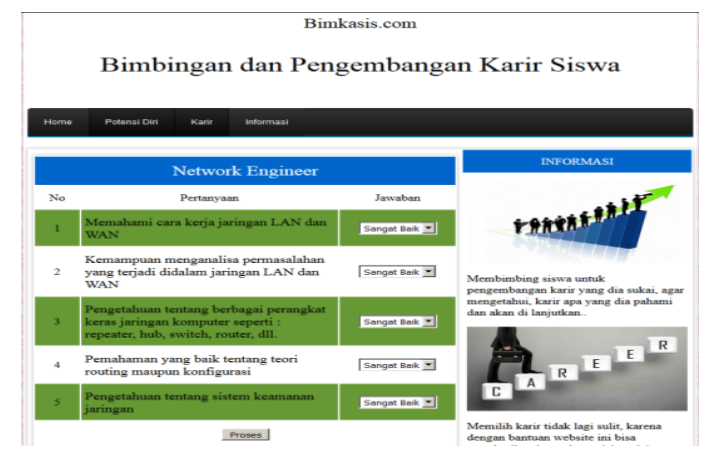

Gambar 6. Tampilan Pertanyaan Pada Konsultasi Seleksi Karir Siswa

Pada halaman tampilan antarmuka diatas terdapat beberapa form pertanyaan yang harus diisi terlebih dahulu oleh siswa karena form ini akan menghasilkan karir yang cocok untuk siswa sesuai dengan minat-bakat atau potensi dirinya. Setelah mengisi form diatas, maka sistem akan memberikan hasil atau informasi kecocokan karir siswa nantinya menggunakan persentase yang didapatkan dari perhitungan menggunakan rumus $\mathrm{CF}$.

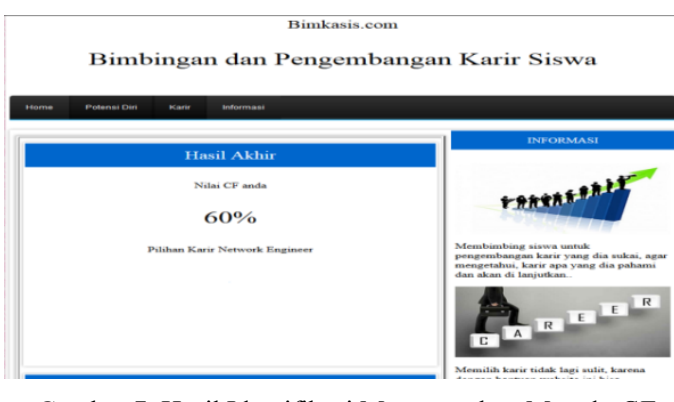

Gambar 7. Hasil Identifikasi Menggunakan Metode $C F$

\section{PENGUJIAN SISTEM}

Dalam penelitian Zulfikar dan teman-temannya (2018) menggunakan black box testinguntuk pengujian software. Pengujian softwareyang dijabarkan dalam tabel 1 digunakan untuk test implementasi sistem secara utuh pada fitur-fitur utama dari software konsultasi seleksi karir siswa yang dapat diilustrasikan pada tabel 1 . 
Tabel 1. Test Case Pengujian Validasi

\begin{tabular}{|c|c|c|}
\hline Fitur Uji & Kondisi & Hasil \\
\hline Login & $\begin{array}{l}\text { User dapat masuk ke sistem } \\
\text { dengan melakukan login } \\
\text { dimana sistem menggunakan } \\
\text { username dan password }\end{array}$ & Valid \\
\hline $\begin{array}{l}\text { List } \\
\text { Konsultasi } \\
\text { Seleksi Karir }\end{array}$ & $\begin{array}{l}\text { Menampilkan menu-menu yang } \\
\text { akan diplih oleh user sesuai } \\
\text { dengan database dan software } \\
\text { yang dibuat. }\end{array}$ & Valid \\
\hline $\begin{array}{l}\text { Hak akses } \\
\text { pendaftran ke } \\
\text { software atau } \\
\text { sistem }\end{array}$ & $\begin{array}{l}\text { Hanya akun hak akses siswa } \\
\text { dan guru yang dapat melakukan } \\
\text { pendaftaran ke software } \\
\text { konsultasi seleksi karir siswa }\end{array}$ & Valid \\
\hline $\begin{array}{l}\text { List mengisi } \\
\text { potensi diri }\end{array}$ & $\begin{array}{l}\text { Menampilkan } \\
\text { pertanyaan sesuai dengan } \\
\text { jurusan, minat-bakat dan karir } \\
\text { yang dipilih }\end{array}$ & Valid \\
\hline List Karir & $\begin{array}{l}\text { Menampilkan Karir yang } \\
\text { diminati siswa sesuai dengan } \\
\text { jurusan dan minat-bakat siswa }\end{array}$ & Valid \\
\hline $\begin{array}{l}\text { Informasi dan } \\
\text { Hasil solusi } \\
\text { karir } \\
\text { menggunkan } \\
\text { CF }\end{array}$ & $\begin{array}{l}\text { Menampilkan informasi solusi } \\
\text { karir yang sesuai dengan } \\
\text { jurusan dan potensi didiri siswa } \\
\text { Proses pemberian CF sesuai } \\
\text { dengan solusi yang dihasilkan } \\
\text { software }\end{array}$ & Valid \\
\hline
\end{tabular}

\section{KESIMPULAN}

Software konsultasi seleksi karir siswa menggambarkan aktifitas didalam pemilihan karir siswa menggunakan variabel minat-bakat, jurusan yang melekat pada diri siswa yang bisa mengarahkan dan mengungkapkan berbagai macam karir. Melaluisistem ini, pengguna yaitupara siswadapat mengenali kemampuan atau potensi dirinya untuk mencapai karir yang diingininya.

Implementasi layanan konsultasi seleksidan pengembangan karir siswa, dapat ditingkatkan dengan menerapkan model bimbingan konsultasi seleksi dan pengembangan karir dengan memberikan informasi karir melalui perangkat lunak konseling seleksi dan pengembangan karir untuk meningkatkan kemampuan perencanaan karir siswa lebih awal.Model perangkat lunak bimbingan seleksi dan pengembangan karier ini menggunakan metode faktor kepastian untuk meningkatkan keterampilan perencanaan karier siswa.

Berdasarkan penelitian ini, menunjukkan bahwa model perangkat lunak bimbingan karir siswa (bimkasis) sebagai media yang baik untuk layanan konseling siswa dan juga tidak hanya untuk komunikasi tetapi juga untuk keterlibatan dalam proses bimbingan seleksi dan pengembangan karir siswa dengan guru. Oleh karena itu, temuan penelitian ini mendukung sudut pandang bahwa perangkat lunak (bimkasis)bimbingan seleksi dan pengembangan karir siswa dapat digunakan sebagai bagian dari meningkatkan dan membangkitkan pengalaman siswa dan guru dalam pengembangan karir masa depan.

\section{UCAPAN TERIMAKSIH}

Ucapan terima kasih kepada Direktorat Riset dan Pengabdian Masyarakat Direktorat Jenderal Penguatan Riset dan Pengembangan Kementerian Riset, Teknologi, dan Pendidikan Tinggi Republik Indonesia telah mendanai penelitian ini dan Sekolah Tinggi Ilmu Komputer Pelita Indonesi.

\section{DAFTAR PUSTAKA}

CHOI, BO YOUNG et al. 2012. Understanding Career Decision Self-Efficacy: A MetaAnalytic Approach. Journal of career development 39(5).

COJOCARIU, VENERA-MIHAELA, AND IRINAVENERA COJOCARIU CIOTIR. 2015. A Study on Raising Awareness of the Students, Needs of Career Counselling. Procedia Social and Behavioral Sciences 180(November 2014): 1058-66.

GRACE, ENECHOJO, AND HAPPINESS IHUOMA. 2013. Relationship Between Counselling And Entrepreneurship Development Skills Of Nigerian Final Year Undergraduates. Procedia - Social and Behavioral Sciences 84(1999): 120-27.

IRWAN, Irwan et al. Perancangan Software Bimbingan dan Pengembangan Karir Siswa dalam Pengambilan Keputusan dan Konsultasi. Jurnal Teknologi Informasi dan Ilmu Komputer, [S.1.], v.4, n. 4, p. 237243, des. 2017. ISSN 2528-6579. Tersedia pada:

$<$ http://jtiik.ub.ac.id/index.php/jtiik/article/vie w/464>. Tanggal Akses: 17 sep. 2018 doi:http://dx.doi.org/10.25126/jtiik.20174446 4.

NUSAI, CHUTCHADA, SIRISAK CHEECHANG, SOMKID CHAIPHECH, AND GORAGOT THANIMKAN. 2015. Swine-Vet: A WebBased Expert System of Swine Disease Diagnosis. Procedia Computer Science 63(Icth): 366-75.

OZDEN, ABDULKADIR, ARDESHIR FAGHRI, AND MINGXIN LI. 2016. Using KnowledgeAutomation Expert Systems to Enhance the Use and Understanding of Traffic Monitoring Data in State DOTs.

Procedia Engineering 145: 980-86. http://dx.doi.org/10.1016/j.proeng.2016.04.12 7.

ROBERT, W, AND STEVEN D BROWN. 2013. Social Cognitive Model of Career SelfManagement: Toward a Unifying View of Adaptive Career Behavior Across the Life Span.journal of counseling psycholog 60(4): 557-68. 
ROCHAT, SHÉKINA, AND JÉRÔME ROSSIER. 2016. "Integrating Motivational Interviewing in Career Counseling : A Case Study." Journal of Vocational Behavior.

WAGNER, WILLIAM P. 2017. Trends in Expert System Development: A Longitudinal Content Analysis of over Thirty Years of Expert System Case Studies. Expert Systems With Applications. http://dx.doi.org/10.1016/j.eswa.2017.01.028.

ZULFIKAR, Rizal Arif; SUPIANTO, Ahmad Afif. Rancang Bangun Aplikasi Antrian Poliklinik Berbasis Mobile. Jurnal Teknologi Informasi dan Ilmu Komputer, [S.1.], v. 5, n. 3, p. 361370, agu. 2018. ISSN 2528-6579. Tersedia pada: $<$ http://jtiik.ub.ac.id/index.php/jtiik/article /view/891>. Tanggal Akses: 17 sep. 2018 doi:http://dx.doi.org/10.25126/jtiik.201853891. 